\title{
ANALISIS PERAN DOSEN SEBAGAIMOTIVATOR BELAJAR DI TENGAH PANDEMIC COVID-19 DI UNIVERSITAS ABDURACHMAN SALEH
}

\author{
Aenor Rofek ${ }^{1}$ \\ ${ }^{1}$ PGSD, FKIP, Universitas Abdurachman Saleh Situbondo \\ e-mail: gonzalesrofik99@gmail.com
}

Received: 17 June, 2020

Revised: 18 June, 2020

Accepted: 21 June, 2020

\begin{abstract}
ABSTRAK
Saat pandemic covid-19 pembelajaran dilaksanakan secara jarak jauh dengan menggunakan berbagai aplikasi. Mahasiswa cenderung lebih malas belajar dikarenakan mereka tidak dipantau secara langsung. Adapun macam-macam motivasi di Universitas Abdurachman Saleh, diantaranya yaitu memberi angka, hadiah, saingankompetisi, Ego-Involvement, memberi ulangan, mengetahui hasil, pujian, hukuman, hasrat untuk belajar, minat dan tujuan yang diakui Motivasi yang diberikan adalah stimulus bagi dosen pengampu mata kuliah pada pembelajaran bahasa Indonesia SD di prodi PGSD. Dari segi ego-involvement, saat ada mahasiswa yang malas mengerjakan tugas kelompok membuat media pembelajaran membaca, dosen memotivasi mahasiswa untuk bekerja keras menyelesaikan tugas, karena tugas tersebut harus dikumpulkan sesuai jadwal. Dosen harus memberikan pujian kepada mahasiswa yang diberikan pujian oleh dosen bahwa hasil pekerjaannya bagus, terihat senang ketika diberikan pujian.

Kata kunci: peran dosen, motivasi, dan mahasiswa.
\end{abstract}

\section{ABSTRACT}

When pandemic covid-19 learning is carried out remotely using a variety of applications. Students tend to be lazy because they are not monitored directly. As for the kinds of motivation at University of Abdurachman Saleh, including giving numbers, prizes, rivals / competition, Ego-Involvement, giving tests, knowing the results, praise, punishment, desire to learn, interests and goals that are recognized. Motivation provided is a stimulus for lecturers in Indonesian language teaching in PGSD study programs. In terms of egoinvolvement, when there are students who are lazy to work on group assignments to make learning media read, lecturers motivate students to work hard to complete assignments, because the assignments must be collected according to schedule. Lecturers must give praise to students who are given praise by the lecturer that the work is good, looks happy when given praise.

Keywords: the role of lecturers, motivation, and students. 


\section{PENDAHULUAN}

Dunia pendidikan adalah dunia yang amat kompleks, menantang dan mulia. Kompleks karena spektumnya sangat luas, menantang karena menentukan masa depan bangsa, dan mulia karena memanusiakan manusia. Kompleksitas tersebut dapat teratasi jika dosen yang menjadi ujung tombak pendidikan Kualitas pendidikan sering menjadi isu sentral dan yang sering menjadi sorotan adalah kualitas dosen. Dosen sebagai salah satu komponen pendidikan memberikan konsekuensi pada pertunya dibekali kemampuan secara profesional dalam melaksanakan tugas. Tugas utama seorang guru terdapat pada Undang-Undang Republik Indonesia Nomor 14 Tahun 2005 tentang Guru dan Dosen, dikemukakan bahwa guru adalah pendidik profesional dengan tugas utama mendidik, mengajar, membimbing mengarahkan, melath, menilai dan mengevaluasi peserta didik pada pendidikan anak usia dini jalur pendidkan formal pendidikan dasar, dan pendidikan menengah (Kompri, 2015: 29).

Pada era masa kini, pendidikan formal salah satunya di perguruan tinggi, belajar selalu dikesampingkan oleh mahasiswa. Berbeda dengan mahasiswa zaman dulu yang memilki keinginan kuat dan berlomba-lomba mencari ilmu dengan belajar. mahasiswa pada zaman dulu setiap berangkat ke kampus ada atau tidak ujian pada hari itu mereka berjalan kaki sambil membaca buku. Sangat berbeda jauh dengan murid zaman sekarang. Apalagi saat pandemic covid-19 dimana pembelajaran dilaksanakan secara jarak jauh dengan menggunakan berbagai aplikasi. Mahasiswa cenderung lebih malas belajar dikarenakan mereka tidak dipantau secara langsung.

Banyak faktor yang memicu mahasiswa kurang termotivasi dalam belajar. Salah satunya, karena mahasiswa beranggapan belajar itu membosankan tidak asik dan sebagainya. Pemicu dari anggapan mahasiswa yang demikian bisa disebabkan oleh faktor guru yang pasif saat proses pembelajaran. Seharusnya dosen harus menciptakan suasana pembelajaran yang aktif dan menyenangkan. Sehingga siswa termotivasi untuk belajar saat proses pembelajaran.

Dalam belajar, selain faktor dosen ada faktor hin yang berpengaruh didalamnya. Faktor tersebut yakni motivasi belajar. Motivasi belajar yaitu ketika seseorang akan melakukan sesuatu pasti ada tujuan yang ingin dicapai dan motivasi atau dorongan untuk melkukan/mewujudkan tujuan tersebut. Motivasi sangat berperan penting bagi kemajuan mahasiswa terlebih saat proses pembelajaran. Begitu pula dalam belajar. Dalam belajar, mahasiswa juga membutuhkan motivasi maka belajar akan menjadi lebih menyenangkan dan lebih semangat. Motivasi belajar dapat berasal dari dalam dirinya sendiri yang disebut motivasi instrinsik dan motivasi yang berasal dari luar dirinya yang disebut dengan motivasi intrinsik (Sardiman, 2014: 89). Karakteristik mahasiswa yang termotivasi dalam 
belajar dan pembelajaran akan terlihat tampak lebih senang, tidak mudah bosan, dan termotivasiterdorong untuk melakukan sesuatu yang diinginkannya. Salah satu faktor penyebab terjadinya hal tersebut ialah adanya kesadaran dalam diri atau dari luar mahasiswa yang ingin/terdorong untuk mencapai keinginannya dengan melakukan sesuatu seperti belajar.

Selain melaksanakan tugas seorang dosen sebagai pengajar yang mengajar peserta didik di kampus, dosen juga memiliki beberapa peran penting, diantaranya sebagai informator, organisator, motivator, pengarah/direktor Inisiator, transmitter, fasilitator, mediator dan evaluator. Terutama dalam meningkatkan motivasi belajar mahasiswa. dosen juga dapat berperan sebagai motivator bagi mahasiswa. Tidak hanya itu, dosen juga harus berupaya sebaik mungkin dalam berbagai hal seperti penampilan, kepribadian dan tingkah laku (Sardiman, 2014: 144).

Begitu juga dalam penguasaan materi, pemithan model pembelajaran, penggunaan bahasa, manajemen kelas yang baik dan masih banyak lagi yang ke semua itu dimaksudkan untuk dapat memberikan motivasi belajar dan suasana belajar yang kondusif dan diminati oleh mahasiswa. Motivasi sangat berhubungan erat dengan perhatian dan sikap dosen sangat berperan penting untuk mendorong mahasiswa agar dapat belajar dengan penuh perhatian. Dengan demikian dosen merupakan salah satu sumber yang sangat penting dalam menumbuhkan motivasi belajar mahasiswa.

Menunt Santrock dalam mardianto (Kompri, 2015: 3) memberikan tiga kata kunci yang dapat diambil dari pengertian psikologi, yakni: 1) dalam motivasi terdapat dorongan yang menjadikan seseorang mengambil tindakan atau tidak mengambil tindakan, 2) dalam motivasi terdapat satu pertimbangan apakah harus memprioritaskan tindakan altematif, baik itu tindakan A atau tindaan B, 3) dalam motivasi terdapat lingkungan yang memberi atau menjadi sumber masukan atau pertimbangan seseorang untuk melakukan tindakan pertama atau kedua.

Dalam memotivasi belajar mahasiswa dibutuhkannya peran dosen sebagai motivator, yang berarti bahwa seorang dosen harus mampu membangkitkan semangat dan mengubur kelemahan anak didik bagaimanapun latar belakang hidup keluarganya, karakteristiknya dan bagaimanapun berat tantangannya. Asmani (2015: 46) menjelaskan bahwa, sebagai seorang motivator, dosen adalah seorang psikolog yang diharapkan mampu menyelami psikologi anak didiknya, sehingga mengetahui kondisi lahir batinnya. Dari pengetahuan ini, seorang guru akan mencari motivasi model apa yang cocok bagi mahasiswa. Adapun macam-macam motivasi di Universitas Abdurachman Saleh, diantaranya yaitu memberi angka, hadiah, saingankompetisi, Ego-Involvement, memberi ulangan, mengetahui hasil, pujian, hukuman, hasrat untuk belajar, minat dan tujuan yang diakui. Dari 
berbagai macam bentuk motivasi yang disebutkan di atas, penting bagi dosen untuk mengembangkan dan menggunakan motivasi belajar yang cocok untuk mahasiswa khususnya di kampus.

Hal tersebut, sejalan dengan apa yang dilakukan dosen-dosen di Universitas Abdurachman Saleh terhadap anak didiknya, tidak hanya menjalankan tugas utama seorang guru, tetapi juga menjalankan perannya sebagai seorang dosen. Salah satu peran yang dijalankan oleh dosen-dosen di Universitas Abdurachman Saleh ialah sebagai motivator bagi anak didik mereka.

Melihat keunggulan yang dimiliki dosen-dosen di Universitas Abdurachman Saleh, salah satunya memilki banyak mahasiswa berprestasi dengan peran dosen sebagai pemberi motivasi, dan dari uraian di atas, maka peneliii tertarik untuk menelii tentang "Analisis Peran Dosen sebagai Motivator Belajar di Universitas Abdurachman Saleh”

\section{METODE}

Menurut Sugiyono (2016), metode penelitian kualitatif adalah metode penelitian yang berlandaskan pada filsafat postpositivisme, digunakan untuk meneliti pada kondisi obyek yang alamiah, dimana peneliti adalah sebagai instrumen kunci dan hasil penelitian kualitatif lebih menekankan pada makna daripada generalisasi.

Pendekatan dalam penelitian ini menggunakan pendekatan kualitatif, karena permasalahan belum jelas, holistik, kompleks, dimamis dan penuh makna. Selain itu, penelifi bermaksud memahami situasi sosial secara mendalam, menemukan pola, hipotesis dan teori. Penelitian lapangan dengan penelitian kualitatif ini membantu peneliti mengeksplorasi bagaimana bentuk peran Dosen dalam memotivasi mahasiswa di Universitas Abdurachman Saleh Situbondo. Kehadiran penelii dalam penelitian ini dilakukan secara partisipatif, karena peneliti akan ikut serta dalam proses belajar mengajar di dalam kelas, peneliti akan melihat secara langsung cara memotivasi dan bimbingan yang dilakukan dosen terhadap mahasiswa dalam memahami materi perkuliahan yang diberikan.

Diharapkan dengan melakukan observasi partisipatif, peneliti akan memperoleh data yang lebih lengkap mengenai bimbingan yang dilakukan guru terhadap mahasiswa di kampus tersebut. Selain itu, peneliti harus bersikap objektif dan netral, sehingga nantinya hasil penelitian tidak berat sebelah atau memihak pada kelompok atau orang tertentu.

Data dalam penelitian kualitatif tidak berupa angka-angka, tetapi berupa narasi (katakata), gambar, foto-foto dan lainnya. Data dalam penelitian merupakan bagian paling terpenting untuk mengupas persoalan- persoalan penelitian. Data diartikan sebagai bahan materi yang berisikan 
informasi, keterangan, dan fakta terkait persoalan penelitian Diantara pengumpulan data yang akan peneliti lakukan meliputi: peran dosen, bentuk dan cara menumbuhkan motivasi, serta faktor pendorong dan penghambat motivasi Sementara untuk memperoleh data tersebut, penelii menggalinya melalui sumber hidup, yaitu mahasiswa, dan dosen di semester IV.

Prosedur pengumpulan data merupakan langkah yang paling strategis dalam penelitian, karena tujun utama dari penelitian adaah mendapatkan data. Sugiyono, dalam bukunya "Metode Penelitian Kuantitatf, Kualitatif dan $R \& D$ ” (2016: 224), membagi prosedur pengumpulan data menjadi empat macam : prosedur observasi, prosedur wawancara, prosedur dokumentasi, dan prosedur triangulasi/gabungan.

Dalam penelirian ini, observasi yang peneliti lakukan lebih pada observasi partisipatif dan observasi terbuka/terus terang. Observasi partisipatif adalah observasi dimana peneliii terlibat dengan kegiatan sehari-hari orang yang sedang diamati atau yang digunakan sebagai sumber data penelitian Sedangkan observasi terbuka adalah observasi dimana peneliti dalam melakukan pengumpulan data menyatakan terus terang kepada sumber data, bahwa sedang melakukan penelitian, Sugiyono (2016: 227-228). Jadi, yang ditelii mengetahui sejak awal sampai akhir tentang aktivitas peneliti.

Dalam upaya kevalidan data penelitian ini diprodi PGSD Universitas Abdurachman Saleh Situbondo, maka peneliti melakukan penelitian melalui observasi langsung selama kegiatan berlangsung. Observasi yang dilakukan terhadap tingkah laku mahasiswa selama kegiatan proses belajar mengajar di kelas dan peran Dosen dalam memberikan motivasi pada mahasiswa, sehingga dapat memberikan data tambahan terhadap hasil wawancara. Dalam pelaksanaan kegiatan ini, peneliti hanya melakukan pengamatan dan mencatat data sesuai kenyataan yang ada.

Wawancara merupakan pertemuan dua orang untuk bertukar informasi dan ide melalui tanya jawab, sehingga dapat dikonstruksikan makna dalam suatu topik tertentu, Esterberg dalam Sugiyono (2016: 231). Sedangkan Stainback dalam Sugiyono (2016: 232) menjelaskan, dengan wawancara, maka peneliti akan mengetahui hal-hal yang lebih mendalam tetntang partisipan dalam menginterpretasikan situasi dan fenomena yang terjadi, dimana hal ini tidak bisa ditemukan melalui observasi. Dokumen yang dapat diambil diantaranya, yaitu data siswa, data guru, kegiatan proses belajar mengajar, sarana dan prasarana, profil sekolah, adminitrasi mengajar.

\section{ANALISIS DATA}

Pada tahapan selanjutnya dalam penelitian ini adalah analisi data. Analisis data merupakan

proses akhir setelah data sudah terkumpul semua, dimana melalui analisi data ini, data yang diperoleh dapat difahami, disimpulkan, dan ditafsirkan. Sebagaimana yang disampaikan Bogdan dalam 
Sugiyono (2016: 243), analsis data adalah proses mencari dan menyusun secara sistematis data yang diperoleh dari hasil wawancara, catatan lapangan, dan bahan-bahan hain, sehingga mudah difahami dan temuannya dapat diinformasikan kepada orang lain. Susan Stainback dalam buku Sugiyono (2014:244) mengemukakan bahwa analisis data merupakan hal yang kritis dalam proses penelitian kualitatif.

\section{REDUKSI DATA}

Menurut Sugiyono (2016: 247) Reduksi data diartikan sebagai proses merangkum memilh hal-hal yang pokok, memfokuskan pada hal-hal yang penting dicari tema dan polanya. Dengan demikian data yang direduksi akan memberkan gambaran yang lebih jelas dan mempermudah penelii untuk melkukan pengumpulan data selanjutnya dan mencarinya bila dipertukan. Reduksi data berlangsung terus menerus selama dan sesudah penelitian di lapangan, sampai laporan akhir tersusun.

\section{PENYAJIAN DATA}

Penyajan data merupakan rangkaian kalimat yang disusun secara logis dan sistematis dan bisa dilakukan dalam bentuk uraian singkat, bagan, hubungan antar kategori, flowchart dan sejenisnya. Kemampuan manusia sangat terbatas dalam menghadapi catatan lapangan yang bisa jadi mencapai ribuan halaman (Sugiyono, 2016: 249). Oleh karena itu, diperlukan penyajian data yang jelas dan sistematis dalam membantu peneliti menyelesaikan pekerjaanya.

\section{HASIL DAN PEMBAHASAN}

Penelitian ini dilakukan secara bertahap yakni dimulai pada tanggal 4 sampai 28 Mei 2020 perkuliahan dilaksanakan seminggu sekali dengan menggunanakan aplikasi zoom meeting sehingga dosen hanya bisa memberikan penguatan dengan memberikan berbagai pujian.

Penelitian ini dimulai pada tahap perencanaan, Dosen terthat sudah memiliki rancangan pelaksanaan Semester (RPS) yang telah dirancang sebelumnya. Sehingga dosen pada saat memulai kelas di zoom meeting sudah siap sehingga mahasiswa sudah bisa mengkondisikan materi, pada saat pandemic Covid 19 ini pembelajaran hanya bisa bisa dilakukan jarak jauh yakni pembelajaran via zoom meeting ataupun whatsapp.

Selanjutnya, pada tahap pelaksanaan, dosen mengucapkan salam mengajak mahasiswa berdoa, memerksa kehadiran dan kesiapan mahasiswa serta memberkan motivasi belajar dengan menyampaikan tujuan pembelajaran. Terihat dosen memberkan motivasi dengan menyampaikan tujuan pembelajaran bahwa tujuan pembelajaran hari ini (melanjutkan yang kemarin) pembelajaran bahasa Indonesia di SD serta mencoba membuat media pembelajaran dan RPP pembelajaran untuk membaca menulis permulaan. mahasiswa pun terlihat mendengarkan dan memahami tujuan pembelajaran yang disampaikan oleh Aenor Rofek, M.Pd. Hal tersebut sesuai dengan pernyataan 
Aenor Rofek, M.Pd. bahwa harus menyampaikan dahulu tujuan pembelajarannya, agar mahasiswa paham dan mengerti apa yang akan dipelajari Begitu juga dengan pernyataan Arief, Rayunda dan Meidy bahwa iya dosen menyampaikan tujuan pembelajaran untuk memudahkan proses pembelajaran via zoom meeting. Pada kegiatan inti, dosen memberikan motivasi, yaitu pertama saingan, dosen memberikan motivasi persaingan dalam pembelajaran saat ada mahasiswa yang malu dan takut untuk bertanya, dengan menyampaikan bahwa "nilai yang didapat mahasiswa yang bertanya pasti diberikan tambahan nilai, yang tidak maju tidak mendapat nilai tambahan". Setelah dosen mengatakan hal tersebut, beberapa mahasiswa tersebut terlihat termotivasi untuk maju karena mereka juga ingin mendapatkan nilai yang bagus seperti mahasiswa yang lain. Hal tersebut sesuai dengan pernyataan Aenor Rofek, M.Pd yang menyatakan, bahwa pernah memberikan motivasi berupa persaingan, seperti dalam tugas antar kelompok maha siswa, pada saat ada mahasiswa yang malas dan tidak percaya diri untuk mengerjakan tugasnya saat disuruh maju ke depan.adapun pandangan yang sama dijelaskan oleh siswa Magfiroh " bahwa mahasiswa yang aktif dan rajin memberikan sanggahan terhadap suatu problem saat perkuliahan biasanya lebih mendapat nilai yang lebih bagus"

Selaku dosen pengampu mata kuliah di prodi PGSD Aenor Rofek, M.Pd biasanya memberi motivasi untuk bersaing dimana saat dosen meminta mengerjakan soal chat zoom meeting yang bisa mengerjakan akan dapat nilai tambahan, hal ini sesuai dengan pendapat Arief dan Dana juga menyatakan diberi motivasi untuk berprestasi pada saat perkuliahan sehingga pada saat pembelajaran semua mahasiswa berlomba-lomba dalam menjawab pertanyaan dari dosen.

Kedua, ego-involvement, saat ada mahasiswa yang malas mengerjakan tugas kelompok membuat media pembelajaran membaca menggunakan kertas manila, dosen memotivasi mahasiswa untuk bekerja keras menyelesaikan tugas, karena tugas tersebut harus dikumpulkan sesuai jadwal. ada yang sudah selesai dan dosen memberikan contoh cara mengerjakannya, agar mahasiswa yang lain berusaha keras untuk menyelesaikan tugasnya. Terthat mahasiswa termotivasi setelah dosen memotivasi mahasiswa untuk berkerja keras dan bekerjasama menyelesaikan tugas individunya, sehingga mahas is wa berusaha keras untuk menyelesaikan tugas tersebut.

Ketiga adalah pujian, dosen terthat memberikan pujian pada mahasiswa yang bisa mengerjakan tugas membuat media pembelajaran dengan baik dan menyampaikan kegiatan mengajar via zoom dengan baik dan benar pada saat perkuliahan zoom meeting berlangsung. Dosen harus memberikan pujian kepada mahasiswa yang diberikan pujian oleh dosen bahwa hasil pekerjaannya bagus, tertihat senang ketika diberikan pujian. Hal tersebut sesuai dengan pernyataan Aenor Rofek, M.Pd bahwa pernah memberikan motivasi dengan pujian saat proses pembelajaran dampaknya sangat luar biasa 
dimana mahasiswa tambah semangat. Senada dengan pernyataaan Leli mahasiswa semester IV PGSD Universitas Abdurachman Saleh yang menyatakan diberi pujian saat membuat tugas media dengan baik dan benar " perasaan saya sangat senang jika hasil media saya di apresiasi oleh dosen, saya akan lebih semangat lagi" .

Keempat ialah motivasi berupa hasrat dan minat untuk belajar, terthat bahwa guru memberikan tugas untuk membuat RPP pembelajaran di SD kelas 1 dan membuat media pembelajaran. Dari hal tersebut, mahasiswa terihat memiliki hasrat dan minat untuk mendengarkan dan mengerjakan tugas yang diberikan dosen dengan sungguh- sungguh. Hal tersebut sesuai dengan pernyataan salah satu mahasiswa bahwa minat belajar akan naik apabila dosen mampu memberikan motivasi kepada mahasiswanya sehingga mahasiswa mempunyai minat belajar, terlihat dari tugas kuliah dan numah yang dikerjakan dari waktu yang diberikan selama 7 hari, ini sudah bisa dikumpulkan lebih cepat yaitu 5 hari anak-anak sudah mampu mengumpulkan tugas media dan RPP (rencana praktek pembelajaran) mengajar.

Pada tahap ke enam adalah evaluasi, dosen memberikan motivasi dengan memberikan penilaian pada mata pembelajaran hari ini untuk mengukur kemampuan mahasiswa, yaitu setelah mahasiswa mengerjakan media dan RPP. Aenor Rofek, M.Pd memberikan penilaian pada mahasiswa yang mengerjakan tugas, pada saat mahasiswa mengerjakan tugas kelompok membuat media dan RPP, maka dosen langsung memberikan angka/nilai pada mahasiswa, setelah mahasiswa mengerjakan tugas. mahasiswa pun terlihat senang saat setiap tugas diberikan nilai oleh dosen Penilaian dosen terhadap tugas meliputi, 3 aspek yang dinilai, yaitu aspek kognitif, afektif dan psikomotoriknya.

Pada tahap ke tujuh adalah tindak lanjut, Aenor Rofek, M.Pd selaku dosen pengampu mata kuliah mengajak mahasiswa menyimpulkan bersama materi hari ini dan menanyakan apa yang tidak dipahami oleh mahasiswa. Saat mahasiswa mengatakan bahwa mereka sudah paham, maka dosen menutup pelajaran di zoom meeting dengan mengajak mahasiswa membaca doa bersama. Hal tersebut mampu membuat suasana mengajar via zoom meeting serasa seperti pembelajaran tatap muka secara langsung. Dampak yang paling terasa ketika dosen bisa membuat mahasiswa termotivasi adalah bagaimana mahasiswa mampu merespon semua materi dan juga semangat dalam mengerjakan tugastugas.

\section{KESIMPULAN}

Berdasarkan hasil peneliian dalam pembahasan yang telah diuraikan di atas dapat disimpulkan bahwa peran Dosen dalam memberikan motivasi belajar pada mahasiswa semester IV Prodi PGSD Universitas Abdurachman Saleh Situbondo sangat penting dan dapat memotivasi mahasiswa dalam 
belajar dan meraih prestasi di bidang akademik dan non akademik.

Dari 11 bentuk motivasi belajar, dosen memberikan 7 bentuk motivasi belajar pada mahasiswa dengan memberikan nilai, saingan/kompetisi, pujian, hukuman, hasrat untuk belajar, minat dan tujuan yang diakui Motivasi belajar yang diberikan oleh dosen mampu mencetak mahasiswa sehingga lebih giat belajar, disiplin, dan bertanggung jawab.

\section{DAFTAR PUSTAKA}

Apriani, Asri (2016). Hubungan Minat Belajar Dan Motivasi Belajar Terhadap Hasil Belajar Siswa Dengan Penerapan Model Pembelajaran Kooperatif Tipe Numbered Heads Together (Nht) Pada Pembelajaran Matematika Pokok Bahasan Keliling Dan Luas Layang-Layang Di Kelas Vii-D Smp Negeri 1 Bayat Tahun Ajaran 2015/2016. Diakses dari https://repository.usd.ac.id/7189/1/121414134.pdf. 2 April 2020.

Arsyad, Azhar. (2013) Media Pembelajaran. Jakarta: Rajawali Pers.

Asmani, Jamal M. 2015. Tips Menjadi Guru Inspiratif, Kreatif Dan Inovatif. Jogjakarta: Diva Pers. Budiono, Teguh. (2012). Hubungan Karakteristik Guru Dan Fasilitas Belajar Dengan Kualitas Pembelajaran Siswa Di Smk Negeri 2 Yogyakarta. http://eprints.uny.ac.id/8467/. 7 April 2020.

Kartika. (2016). Peran Guru Dalam Memotivasi Belajar Siswa Pada Mata Pelajaran Ips $\begin{array}{llllll}\text { Terpadu Di Smp } & \text { Pgri } & \text { Ciledug. Diakses }\end{array}$ http://repository.uinjkt.ac.id/dspace/bitstream/123456789/32763/1/Soraya.pdf10 April 2020.

Kompri. (2015). Motivasi Pembelajaran Perspektif Guru Dan Siswa. Bandung:

PT Remaja Rosdakarya.

Ningsih, Yusria. (2014). Perkembangan Peserta Didik. Surabaya: Revka Petra Media.

Putri, Melina Eka. (2012). Pengaruh Kebiasaan Belajar Dan Persepsi Siswa Tentang Metode Mengajar Guru Terhadap Prestasi Belajar Ekonomi Siswa Kelas X SMA N 1 Patuk Gunungkidul Tahun Ajaran 2011/2012. http//eprints.uny.ac.id/id/eprint/8883. 10 April 2020.

Rosyada, Dede. (2017). Madrasah Dan Profesionalisme Guru Dalam Arus Dinamika Pendidikan Islam Di Era Otonomi Daerah. Depok: Kencana.

Sardiman. (2014). Interaksi dan Motivasi Belajar Mengajar. Jakarta: Rajawali Pers.

Slameto. (2013). Belajar dan Faktor-faktor yang Mempengaruinya. Jakarta: Rineka Cipta Kuantitatif, Kualitatif dan Sugiyono. (2016). Metode Penelitian R\&D.Bandung: Alfabeta. 